MATEC Web of Conferences 46, 02003 (2016)

DOI: $10.1051 /$ matecconf $/ 20164602003$

(C) Owned by the authors, published by EDP Sciences, 2016

\title{
New methods for testing fire resistance of wood façade systems
}

\author{
August Mårtensson
}

Brandkonsulten AB/Luleå University of Technology Stockholm, Sweden

\begin{abstract}
Arson in schools has been a huge problem in Sweden over the last fifteen years. The average amount of school arsons between 2000 and 2014 was 285 cases each year which corresponds to $50 \%$ of the total amount of reported fires in school buildings. This is a well-known problem and a lot of research has been done in this area. Investigations has been done about fire and heat detection systems, different technical factors significance in fire scenarios and how to prevent adolescents from starting fires.

Another part of the problem that partly been investigated is how the schools are constructed. Roughly $50 \%$ of the arsons are outside of the school building. In Sweden one and two storey buildings are allowed to be built with wooden façades in accordance with the building code, which is one of the reasons many schools are built with wooden façade systems.

The most critical part in a wood façade system from a fire safety perspective is concluded to be the eaves because of how they usually are built to let air pass through. Even though a wood façade isn't as well resistant to fire compared to a concrete façade, three versions of new test methods for combustible façades have been developed to make it possible to make sure in advance that a construction is resistant enough.

The new test methods are focused on specific details and parts of a façade system to provide a more informative and useful result compared to SP Fire 105. Observations and measurements of flame spread and temperature changes in the eave, over the window joints and in the air gap are made. With these parameters in consideration criteria's has been chosen for a critical temperature of $280^{\circ} \mathrm{C}$ at a critical time of 20 minutes.
\end{abstract}

\section{INTRODUCTION}

In Sweden about 600 school fires occurs each and every year since 2000 and about half of them are caused by arson. It costs the society approximately 50 million euro's every year [1]. Studies and projects have been performed over the last fifteen years to solve this problem by investigating how these fires may be detected earlier and how to lower the occurrence of fires caused by arson.

One of the main reasons to the high costs is, except for the high number of fires, also that many fires ends in total damage and the buildings must be rebuilt from the ground [2]. If the fire is spreading into the building damages will be made from the smoke but also by the extinguishing water.

This is an Open Access article distributed under the terms of the Creative Commons Attribution License 2.0, which permits unrestricted use, distribution, and reproduction in any medium, provided the original work is properly cited. 


\section{MATEC Web of Conferences}

\subsection{Question formulation and purpose}

The following questions were formulated to be answered in the study:

- Is it possible to identify any patterns regarding specific weak parts in wooden façade constructions in school buildings?

- May façades consisting of wood be designed to prevent fire from spreading inside the wall and past separating structures?

- Is a new test method needed and are there any uses for such?

- How could a new test method be designed and customized for wooden school façades?

One purpose with this project has been to evaluate the possibility of finding a way to make it possible to reassure a wood façade system is moderately resistant against fire. In addition to that, also suggest how test methods could be designed to fulfil that purpose.

Another purpose was to investigate the need for special demands regarding specific elements in a wooden façade system and how these elements could be tested. A big part of this study is dealing with how this type of façade system can be tested and how a new test method for the same purpose could be designed.

\subsection{Limitations}

Developing a new test method has been determined to be too time consuming for this study. The test methods presented in this report are rough and must be carefully evaluated before they may be practiced.

\section{METHOD}

The information is based on statistics regarding the extent of the problem with school fires caused by arson. It is also based on and supported by statistics about how often buildings with wooden façades are burning. By processing this information it can be concluded which parts and details of a façade system that are less able to resist fire and be specific evaluated in new test methods.

The statistics comes mainly from the database IDA presented by the the Swedish Civil Contingencies Agency (MSB. In addition interviews have also been held with experts on the subjects of fire resistance and test methods for façade systems. The existing Swedish method for testing façades fire resistance, SP Fire 105, has been used as a base for the presented examples of new methods.

During this study other test methods have also been studied. Even though they have been established to be used for different scenarios they have been developed over a long time which is valuable. Experiences from other test methods can be of great use when creating new methods adjusted for the specific conditions described above.

\section{STATISTICS AND THEORY}

The statistics collected from the database IDA is based on reports written by the fire brigades in Sweden. These reports are filled out after every incident by one of the firemen and then sent to MSB. It could have been possible to collect statistic from other sources in this project, e.g. from the crime preventing counsel or from the insurance companies, but an assessment has been made that the statistics from MSB is sufficiently detailed for its purpose in this work, which is to make the reader understand the proportions of school fires caused by arson in Sweden. Deviations that might have been identified comparing different statistics is therefore concluded to be of less interest.

During the period 2000-2014 the fire brigade have been called out to school fires about 8000 times. Of these fires almost 4000 have been caused by arson, which is almost 50\% [3]. Since 2000 the number 


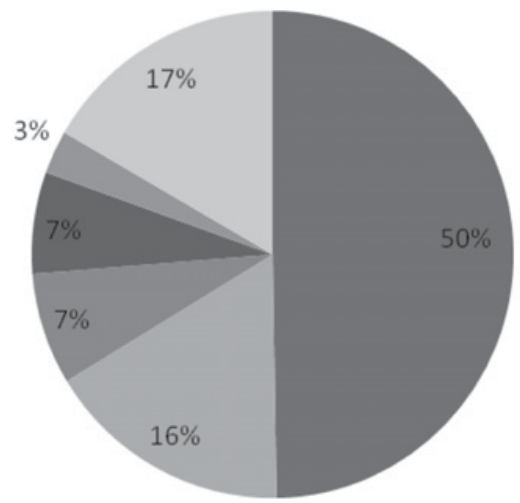

- Cauesd by arson

घunknown

Technical error

Childrens play with fire

a Fireworks

Other

Figure 1. Percentage of contribution to fires in schools in Sweden during the years 2000-2014 sorted by cause.

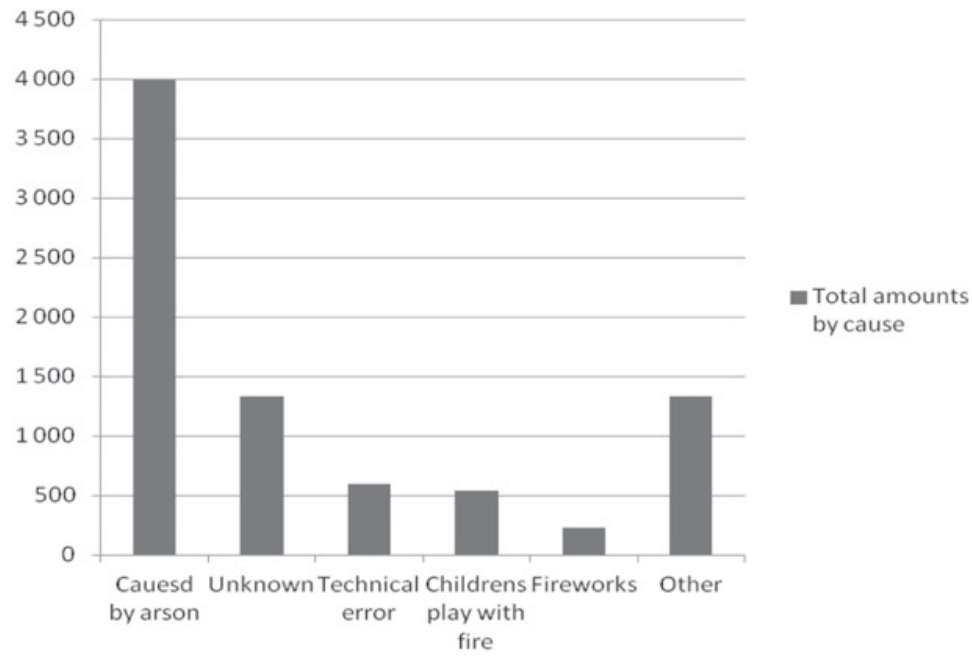

Figure 2. The amounts of different causes to fire in schools during 2000-2014.

of school fires caused by arson in Sweden is approximately 270 each year. $16 \%$ of the amount of 8000 is said to be by unidentified cause. That corresponds to 85 fires each year. The distribution and total amounts of different causes to school fires are presented below in Figs. 1 and 2.

School fires caused by arson is a well known problem in Sweden. A lot of studies and research has been done during the latest years, for instance in the project "Anlagd brand" ("Arson" in English) which was initiated in 2007. The final report of this project was presented in 2013 and it includes the results of various studies on the area [4]. One major part of the project was to find a way to lower the amounts of school fires caused by arsons. The purpose of this study, however, is to make it possible to build more fire safe constructions without raising the legal requirements for approved surface materials in façade systems, and thereby reduce the consequences when a fire occur.

\subsection{Swedish laws and regulatory requirements}

The law requirements of approved surface materials for a building are regulated by the use of the building and the number of storeys. It is also regulated by what kind of activities the building houses. 


\section{MATEC Web of Conferences}

For instance it differs if it's a house with apartments or a house with offices. Mentioned factors divides buildings into different building categories according to Swedish building regulations [5]. A building in two stories used for school activities is assigned to building category $\mathrm{Br} 2$. For buildings in category $\mathrm{Br}$ 2 or $\mathrm{Br} 3$ it is permitted to use materials of class $\mathrm{D}-\mathrm{s} 2, \mathrm{~d} 2$ on the façade surface. This class corresponds to untreated wood panel. Since many newly built schools belong to building category $\mathrm{Br} 2$ it is also common they are built with wood façades.

\subsection{The significance of the fire brigade}

When smoke is detected or a fire is identified in some way the fire brigade is called and arrives to the area of fire. When a building in category $\mathrm{Br} 2$ is designed the main purpose from a fire safety perspective is to make sure no one will be harmed in case of fire. However, the fire brigade also have the possibility to constrain the damage made on the building. The fire brigade have different resources and ability in different areas in Sweden when it comes to staff, equipment and driving time to villages. That is important to have in mind when a new school is built. A more fireproof façade can prevent massive damage on a building, but only for a limited time.

\subsection{Characteristic fire scenarios and existing test methods}

There are different existing methods to test the properties of façade systems. The different methods are used in different parts of the world and are designed for different purposes. In Sweden it is one method commonly used and mentioned in the building regulations. The name of this method is SP Fire 105 and is a full scale test where the set up consists of a façade construction in two stories, $6.71 \mathrm{~m}$ high and $4.0 \mathrm{~m}$ wide.

SP Fire 105 was designed during the nineties when buildings in Sweden in a great extent where additionally insulated with combustible insulation covered with protective plaster. Since then the method has been used more and more and by the time the regulations has sharpened, the method has been established as a part of the building regulations. As fuel in the test method 60 liters of heptane in a barrel is used. The method is intended to represent a realistic fire scenario where the flames have broken out through a window in a compartment after a flashover [6].

A international standard is also used to test the fire resistance of façades. The method is divided into two parts where part 2 is called Large-scale test [7]. It is similar to SP Fire 105 with a scenario of a fully developed fire spreading out through an opening from a compartment after flashover where the façade outside the compartment is tested.

Part 1 is a smaller version of Part 2 and is used when a large test isn't required [8]. These two tests are exclusively designed to test the properties of the material on the façade surface. They do not consider variations or details in a façade. SP Fire 105 is better in that way since it is built with fictive windows and with an eave where temperatures are measured [6].

\section{TECHNICAL FACTORS SIGNIFICANCE IN CASE OF FIRE}

In a substantial report as part of the Arson-project mentioned above, the significance of different technical factors regarding fire is analyzed [9]. The results in the report are built on a survey answered by 37 Swedish fire investigators. This report has been an important source of information in this study and in designing a new test method. By focusing on these specific details in the test method and to have them carefully evaluated, the opportunity of limiting fire spread is made.

According to the statistic database IDA [3] school fires caused by arson started outside the buildings varies between 70-110 cases during 2004-2014. The most common places for arson outside a school is right next to the façade, next to the entrance, close under the roof or in the crawl space [9]. 


\subsection{Eaves}

The eave should be built with separating properties corresponding to EI 30 to stop fire spread to the attic. EI 30 corresponds to stopping heat and smoke during a fire for 30 minutes. Otherwise the fire might quickly spread to other parts of the building. However, when the attic belongs to the same fire compartment as the storey bellow, which is common in buildings of category $\mathrm{Br} 2$, there are no regulations concerning the eaves [10].

The design of the eave in façade systems has a huge impact of the possibility to fire spread and is the foremost weakness in the façade systems of schools [9]. When a fire is started next to a façade it is mainly through the eave it spreads. Eaves are, because of this, important to include in a new test method.

\subsection{Penetrations in the façade}

A façade is not made by a single, flat wall. Often, if not always, there are details and installations integrated such as ventilation devices etc. When a penetration in the façade is made it is of great importance that the opening is well sealed. With this kind of details in the façade the risk of fire and smoke spread in the building increases [9].

\subsection{Mounting of windows}

The way windows are mounted in a façade is also of great importance. Like other penetrations for different installations the frame for a window must be carefully sealed to avoid fire and smoke spread in the façade system. If the construction holding the window is badly executed it is possible for fire and smoke to find its way into the façade system and spread inside the wall in the air gap [6].

\subsection{Air gaps}

To keep a wood façade ventilated and to avoid moisture damages it is common an air gap is part of the façade system. An air gap is also creating beneficial conditions for fire spread if a fire, somehow manage to get there. It is because of the openness of the cavity and the access to oxygen. The air gap, however, is not mentioned as a weakness of a façade system and has not been said to have been the reason of a serious school fire in Sweden [9]. It will still be included in the test method since it is considered to be a weakness of the façade system.

\section{ARSON SCENARIOS AND SOURCE OF FIRE}

In the new test method it is desirable that the source of fire represents an expected and realistic fire scenario for school fires caused by arson. In a report, four expected scenarios are presented and two of them are outside the school, next to its façade [11]. The two scenarios are:

1. Trash/combustible liquid placed by the façade.

2. Motorcycle/moped placed by the façade.

These two scenarios are described as common in school fires caused by arson. The heat release rate (HRR) varies between the different cases but do also depend on what kind of trash, what kind of liquid or what kind of vehicle that is used.

The category Car or other vehicle has been used as igniting source 20 times between the years 20042014 according to IDA. That is less than two times every year. However, many of the school fires with the most serious consequences have been started with a vehicle as igniting source. An experiment shows that a burning motorcycle can reach a maximum HRR of $1300 \mathrm{~kW}$ and a heat radiation corresponding to 


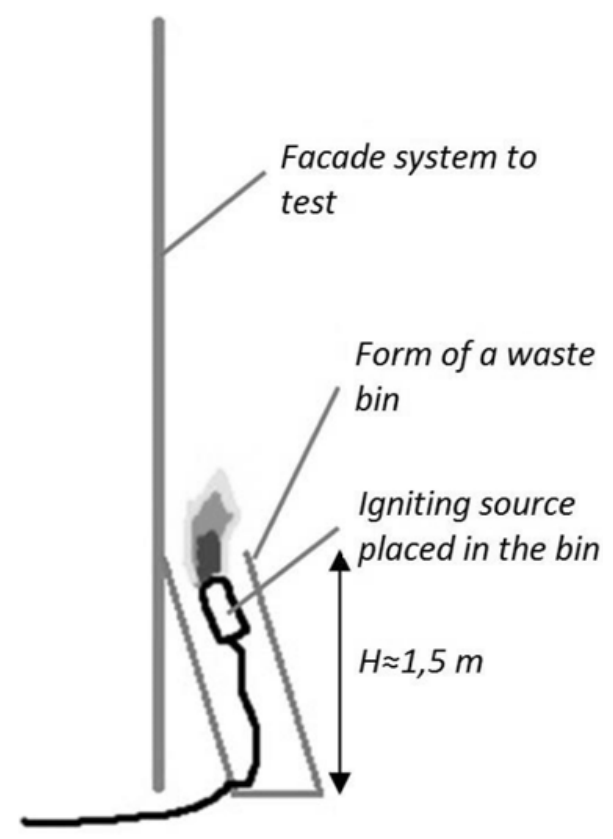

Figure 3. Igniting source corresponding to a waste bin.

$30-70 \mathrm{~kW} / \mathrm{m}^{2}$, and temperatures higher than $300^{\circ} \mathrm{C} 3 \mathrm{~m}$ above the vehicle. [11] In the new test method the source of fire and its HRR can be adjusted to correspond to scenario 1 or 2 . It is a decision to make for the client ordering the test, why it is desirable that more than one HRR is possible.

A 1251 waste bin made of poly ethylene will reach a maximum HRR of $350 \mathrm{~kW}$ after about two minutes. The HRR also depends on the density and specific kinds of trash. A gas burner may be used as igniting source which can be placed leaning against the façade.

\subsection{Design of burner}

Two different designs of burners should be developed. One design for each scenario explained above.

The effect of the igniting source of each burner can be adjusted to a linear rising from 0 to 350 and $1300 \mathrm{~kW}$ in two minutes and then kept steady over a specified time according to the clients demands. The design of the source of fire should look like an actual waste bin or an actual motorcycle. The one corresponding to a waste bin can be leaned against the façade as in Fig 3. The one corresponding to a motorcycle can have a similar design, but only a bit lower and wider.

\section{RESULTS THE TEST WILL GENERATE}

After a façade has been tested according to the new method the results should be presented describing how well it resisted the fire scenario. In this chapter the relevant information which should be obtained from each technical detail of the façade system is described.

\subsection{Eaves}

As mentioned earlier the eave is probably the most critical part of the façade system in a fire scenario. To generate a result regarding the fire resistance of the eave the temperature should be measured on 


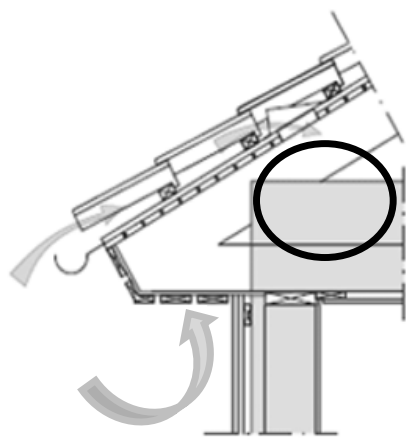

Figure 4. Eave with place to put a thermocouple and piece of cotton circled.

the inside of the eave. In addition to the temperature a piece of cotton may be placed inside the eave and observed during the test. It should then be noted at what time the piece of cotton ignites and the temperature curve shall be presented. The thermocouple and the cotton piece should be placed in the circled area in Fig. 4, but separated from each other.

\subsection{Penetrations in the façade}

It is desirable to create a standardized penetration in the façade and install a detail that will be used in the real façade system, within the hole. It should then be sealed accordingly to descriptions and how it is meant to be performed at the building place. A thermocouple may then be placed inside the façade construction above the hole so temperature varieties can be measured. Sudden temperature raises will indicate if the flames have spread into the wall. The temperature curve and moment of spread into the wall shall be documented.

\subsection{Mounting of windows}

By building a façade system with fictive windows like described in SP Fire 105 the frames which are to be used may be installed in the set up and tested. By mounting the window frame which shall be used in the building and sealing the construction with a noncombustible board behind the frame to keep the fire from the back side, the mounting can be tested. In the same way as above a thermocouple can be placed inside the façade system over the window frame. Sudden temperature raises will indicate if the flames have spread into the wall. The temperature curve and moment of spread into the wall shall be documented.

\subsection{Air gaps}

To test the air gap a thermocouple may be placed inside it. If the cavity shall be divided by fire stops it shall also be so in the test. Then thermocouples shall be placed on each side of the separating detail. Sudden temperature raises will indicate if the flames have spread into the air gap. The temperature curve and moment of spread into the wall shall be documented. 


\section{MATEC Web of Conferences}

Table 1. Symbols and explanations of the different parameters obtained as result from the test method.

\begin{tabular}{l|l} 
Symbol & Explanation \\
\hline $\mathbf{A}_{\mathbf{x}} \mathbf{y} \mathbf{y}$ & Size of fire and test time. \\
$\mathbf{B z}$ & Measure of fire spread inside and on the façade. \\
$\mathbf{C}$ & Tested with fire stop by the eave. \\
$\mathbf{D}$ & Tested with sealed penetration in the façade. \\
$\mathbf{O}_{\mathbf{n}}$ & Other details included in the test which should be specified.
\end{tabular}

\section{METHODS OF CLASSIFICATION}

In this following chapter three different methods of classifications will be described. They are formed differently to make it possible to compare them to each other and make it possible to develop one or more into a good and reliable test method.

\subsection{Requirements the façade must endure}

Three factors that should be possible to measure are presented. They are described in what way they may be accepted. The following factors shall be considered during a test.

- Fire spread on the surface. That the surface of the façade is burning is not necessary a problem. However, if it is clear that the spread is so aggressive the flames reach the eave, the eave should be protected with some kind of fire stop. If the fire spread is limited and the flames are low the façade system may be built without extra requirements regarding the eave.

- Fire spread inside the façade. Depending on the construction of the façade system a fire might find its way into the wall. In a ventilated façade the fire can quickly spread through the air gap and move up the building. Technical details can also be part of fire spread inside the wall. After a test the fire spread inside the wall should be evaluated. If the spread is considered to be too serious, fire stops may have to be installed in the cavity.

- Fire spread through the eave into the attic. If the fire spread through the eave and into the attic (which is supposed to be behind the eave) measures must be taken. If the fire has spread into the attic it can quickly move to other parts of the building. That's why this kind of spread must be prevented. This can be helped by some kind of fire stop.

\subsection{Method 1}

The following method of classification has been developed to look like the European standard EN 13501-1:2007 that is used to determine materials reaction to fire. The classification is defined letters and numbers to explain what's been tested and which results that are achieved. The same method of classification is used in method 1 , although the letters and numbers have a different meaning. Below in Table 1 the different parameters are listed and explained.

With definitions according to table 1 and the letters $\mathrm{x}, \mathrm{y}, \mathrm{z}$ and $\mathrm{n}$ corresponding to numbers a façade could be classified as in example 1 and 2 bellow where parameters are combined after achieved result.

Example 1: Tested with a fire load of category 2 for 15 minutes with a fire spread corresponding to the requirements fulfilling criteria 1 , tested with fire stop by the eave.

$$
\mathrm{A}_{2} 15, \mathrm{~B}_{1}, \mathrm{C}
$$

Example 2: Tested with a fire load of category 1 for 30 minutes with a fire spread corresponding to the requirements fulfilling criteria 3 , tested with a specific detail corresponding to $\mathrm{O}_{1}$.

$$
\mathrm{A}_{1} \mathbf{3 0}, \mathrm{B}_{3}, \mathrm{O}_{1}
$$


Table 2. Grading criteria's for measurements and observations from the test method.

\begin{tabular}{|c|c|c|c|c|c|}
\hline Method 2 & $\mathbf{0}$ & 1 & 2 & 3 & 4 \\
\hline Eave (points*2) & $>280^{\circ} \mathrm{C}$ & $>280^{\circ} \mathrm{C}$ & $<280^{\circ} \mathrm{C}$ & $>280^{\circ} \mathrm{C}$ & $<280^{\circ} \mathrm{C}$ \\
\hline Temperature & in $10 \mathrm{~min}$ & after $10 \mathrm{~min}$ & after $10 \mathrm{~min}$ & after $20 \mathrm{~min}$ & after $20 \mathrm{~min}$ \\
\hline Piece of cotton & $\begin{array}{l}\text { ignition }< \\
5 \text { min }\end{array}$ & $\begin{array}{l}\text { ignition }< \\
10 \text { min }\end{array}$ & $\begin{array}{l}\text { ignition }< \\
15 \mathrm{~min}\end{array}$ & $\begin{array}{l}\text { ignition }< \\
20 \mathrm{~min}\end{array}$ & $\begin{array}{l}\text { ignition }> \\
20 \mathrm{~min}\end{array}$ \\
\hline Penetration & $>280^{\circ} \mathrm{C}$ & $>280^{\circ} \mathrm{C}$ & $<280^{\circ} \mathrm{C}$ & $>280^{\circ} \mathrm{C}$ & $<280^{\circ} \mathrm{C}$ \\
\hline & & & & & \\
\hline Mounting of window & $>280^{\circ} \mathrm{C}$ & $>280^{\circ} \mathrm{C}$ & $<280^{\circ} \mathrm{C}$ & $>280^{\circ} \mathrm{C}$ & $<280^{\circ} \mathrm{C}$ \\
\hline Temperature & $10 \mathrm{~min}$ & after $10 \mathrm{~min}$ & after $10 \mathrm{~min}$ & after $20 \mathrm{~min}$ & after $20 \mathrm{~min}$ \\
\hline Temperature & $\begin{array}{l}>280^{\circ} \mathrm{C} \\
\text { in } 10 \mathrm{~min}\end{array}$ & $\begin{array}{l}>280^{\circ} \mathrm{C} \\
\text { after } 10 \mathrm{~min}\end{array}$ & $\begin{array}{l}<280^{\circ} \mathrm{C} \\
\text { after } 10 \mathrm{~min}\end{array}$ & $\begin{array}{l}>280^{\circ} \mathrm{C} \\
\text { after } 20 \mathrm{~min}\end{array}$ & $\begin{array}{l}<280^{\circ} \mathrm{C} \\
\text { after } 20 \mathrm{~min}\end{array}$ \\
\hline
\end{tabular}

Table 3. Grading criteria's for measurements and observations from the test method.

\begin{tabular}{l|l|l} 
Points & Grade & Explanation of grade \\
\hline $\mathbf{2 4 - 2 8}$ & A & $\begin{array}{l}\text { Achieved points indicate strong protection against spread of fire in } \\
\text { and through the façade system. }\end{array}$ \\
$\mathbf{2 0 - 2 4}$ & B & $\begin{array}{l}\text { Achieved points indicate quite strong protection against spread of fire in } \\
\text { and through the façade system. }\end{array}$ \\
$\mathbf{0 - 1 4}$ & D & $\begin{array}{l}\text { Achieved points indicate quite week protection against spread of fire in } \\
\text { and through the façade system. }\end{array}$ \\
Achieved points indicate week protection against spread of fire in \\
and through the façade system.
\end{tabular}

Furthermore the parameters and categories need be defined and adjusted after desirable regulation level which may vary between tests.

\subsection{Method 2}

A grading system has been developed for technical factors presented in the article as weaknesses in a façade system. Possible points per measure/observation vary between $0-4$ where 4 is the highest point to be achieved for each detail. However, since the eave is concluded to be the most critical detail in the façade system its points are doubled. Possible amount of points is between 0-28. Below in Table 2 the criteria's for each measurement/observation is described.

Table 3 that follows is used to classify the façade system after achieved points are summarized. The highest grade is A and the lowest D. The grades may be adjusted.

\subsection{Method 3}

For technical factors in the façade system described as weaknesses in this article, five criteria have been developed. In method 3 all criteria must be fulfilled for the façade system to be approved as fireproof. The same criteria are included in method 2 but in method 3 they are presented as requirements instead of scoring factors. The requirements that need to be fulfilled are presented bellow in Table 4 . In this example 20 minutes is used as a critical time, but it is possible to adjust critical time and temperature after a clients demands. 
Table 4. Grading criteria's for measurements and observations from the test method.

\begin{tabular}{l|l} 
Method 3 & \\
\hline Temperature & $\begin{array}{l}\text { Eave } \\
<280^{\circ} \mathrm{C} \text { after } 20 \mathrm{~min} \\
\text { Ignition }>20 \mathrm{~min}\end{array}$ \\
Piece of cotton & $\begin{array}{l}\text { Penetration } \\
<280^{\circ} \mathrm{C} \text { after } 20 \mathrm{~min}\end{array}$ \\
Temperature & $\begin{array}{l}\text { Mounting of window } \\
<280^{\circ} \mathrm{C} \text { after } 20 \mathrm{~min}\end{array}$ \\
Temperature & $\begin{array}{l}\text { Air gap } \\
<280^{\circ} \mathrm{C} \text { after } 20 \mathrm{~min}\end{array}$ \\
Temperature & $<$
\end{tabular}

\section{ANALYSIS AND CONCLUSIONS}

\subsection{The need and use of new test methods}

The conclusion is that existing methods many times are too tough for the purpose of testing against school fire caused by arson. Furthermore existing methods are not adjusted to take the weaknesses of a façade system into account. This is something a new test method should incorporate.

\subsection{Identified patterns and technical factors significance in case of fire}

Fire spread through the eave and up to the attic have been concluded to be the most common cause of fire spread from school fires caused by arson. If it is possible to make sure a fire doesn't spread through the eave a big amount of resources can be saved. It can lower the number of total damages of school buildings significantly which can save the society a lot of money. Other technical details mentioned in this article should also be included in a new test report. It won't be hard to integrate those parts and it may point out weaknesses that can be corrected before a school is built.

\subsection{Critical time and temperature}

In method 2 and 3 for classification a critical temperature is chosen to be $280{ }^{\circ} \mathrm{C}$ and a critical time is set to 20 minutes. What should also be said about this is that critical time and temperature may be adjusted. What is considered to be a reasonable critical time and temperature may however vary between different buildings and areas because of the fire brigades resources etc.

\section{References}

[1] Höjer, H., Svenska skolor brinner mest [Swedish schools burn the most]. Forskning \& Framsteg. \#7. 14-17, 2012.

[2] Zetterström, H-E., Fire and risk engineer at the department of risk and damage techniques at Länsförsäkringar, interview, September $17^{\text {th }} 2015$.

[3] Swedish Civil Contingencies Agency (MSB), Statistics database - Fires in buildings, http: //ida.msb.se/ida2\#page=a0109, 20150901.

[4] Anlagd brand [Arson], Brandforsk särskild satsning om anlagd brand, http://anlagdbrand.se/sv/Sidor/default.aspx, 2015-09-21.

[5] Boverket, Boverkets byggregler 22, Karlskrona, Sweden, 2015.

[6] Boström, L., Department of fire resistance at SP Technical Research Institute of Sweden, Fire Research, Borås, Interview, September $11^{\text {th }} 2015$. 
$2^{\text {nd }}$ International Seminar for Fire Safety of Facades, Lund (Sweden), 2016

[7] ISO copyright office, International standard, ISO 13785-2, Reaction-to-fire tests for façades Part 2: Large-scale test, Geneva, Switzerland, 2002.

[8] ISO copyright office, International standard, ISO 13785-1, Reaction-to-fire tests for façades Part 1: Intermediate-scale test, Geneva, Switzerland, 2002.

[9] van Hees, P \& and Johansson, N., "Use Of Case Studies To Determine Technical Deficiencies With Respect To Fire Spread In School Buildings,", Report: 3148), ISSN: 1402-3504. Lunds Faculty of engineering, Lund, Sweden, 2010.

[10] Björkman, B., Fallqvist, K., and Klippberg, A., BBR: Brandskydd i boverkets byggregler, ISBN: 978-91-7144-440-0, Brandskyddsföreningen, Stockholm, Sweden, 2014.

[11] Klason, L-G., Johansson, N. \& P. Andersson, Dimensionerande brand: anlagda skolbränder, [Design fires: arson in school buildings], report 2010:15, SP Technical Research Institute of Sweden, Borås, Sweden, 2010. 